\title{
Nutritional supply of proteins and absorption of their hydrolysis products: consequences on metabolism
}

\author{
BY ALAIN A. RÉRAT \\ Batiment 405, CRJ-INRA, 78350 Jouy-en-Josas, France
}

Except in nibblers such as the rat the food intake of single-stomached animals, particularly omnivores, is discontinuous and varies in amount and composition. These quantitative and qualitative variations in food intake pose a number of questions. Do they affect the digestive processes which are related to food transit and enzyme hydrolysis, especially the extent of nutrient absorption and its kinetics? What effect do they have on the storage of nutrients in the liver and the temporal distribution in the tissues? Do they lead to a modification of the nutritive value?

These questions cannot be answered merely by measuring digestibility. Digestibility is used to evaluate the disappearance of ingested nutrients either in the whole digestive tract (rectal digestibility) or in its proximal part (ileal digestibility), where the nutrients are not metabolized by the flora and are, thus, absorbed in their initial form of diet components. Whichever technique is used, these digestibility measures are global and static and do not account for the different absorption rates which vary for different nutrients. Since body reserves of free amino acids are small, the relative timing of the input of amino acids and of carbohydrates can markedly affect protein synthesis and the efficiency of feed utilization (Geiger, 1950). For example, if a pig is supplied with a limiting amino acid (AA) at a time other than when the rest of the diet, deficient in that one AA, is given the growth rate and feed efficiency will be lower than when the diet and supplement are given simultaneously (Rérat \& Bourdon, 1975). Study of kinetics associated with differences in the relative absorption rate of the various nutrients is necessary for a fuller understanding of variations in the nutritive value of feeds. Also, the chemical substances which appear in the body during digestion must be identified so that we may evaluate the changes in feeds which result mainly from microbial metabolism, as they pass through the digestive tract and during their transport by the enterocyte. The importance of these transformations is that they can lie at the origin of changes in their nutritive value.

The use of a technique which allows direct measurement of intestinal absorption and hepatic metabolism of nutrients has helped to resolve some of these problems. The technique has allowed assessment of the amounts of nutrients appearing in blood, their composition and changes with time, as well as the kinetics of their uptake and release by the liver. Furthermore, it has provided us with an appreciation of the endocrine reactions of the enterohepatic axis involved in the regulation of absorption and metabolism.

This paper reports some findings relating to proteins and gives experimental results obtained in our laboratory on the kinetics of intestinal absorption of nitrogenous nutrients and their consequences for hepatic and peripheral metabolism.

\section{METHODOLOGY}

The method used for studying absorption and liver metabolism (Rérat, 1988; Rérat et al. 1992 ) is based on the quantitative determination of the fluxes of splanchnic input (QES), 
hepatic influx (QEH) and splanchnic or hepatic efflux (QSH) during the period, dt, from measurement of nutrient concentrations in the arterial blood (Ca), portal blood (Cp) and posthepatic blood (Cvs) and of the blood flow-rate in the portal vein (Dp) and hepatic artery $(\mathrm{Da})$, according to the formulas:

$$
\begin{aligned}
& \mathrm{QES}=\mathrm{Ca}(\mathrm{Dp}+\mathrm{Da}) \mathrm{dt}, \\
& \mathrm{QEH}=[(\mathrm{Cp} \times \mathrm{Dp})+(\mathrm{Ca} \times \mathrm{Da})] \mathrm{dt}, \\
& \mathrm{QSH}=\mathrm{Cvs}(\mathrm{Dp}+\mathrm{Da}) \mathrm{dt} .
\end{aligned}
$$

Thus, all blood inputs and outputs in the abdominal splanchnic area, through all the abdominal viscera was measured. Three variables based on the efflux-influx values were deduced from these formulas: intestinal balance (BI), hepatic balance (BH) and the balance in the peripheral tissues (BT) which includes urinary excretion:

$$
\begin{aligned}
& \mathrm{BI}=\mathrm{QEH}-\mathrm{QES}, \\
& \mathrm{BH}=\mathrm{QSH}-\mathrm{QEH}, \\
& \mathrm{BT}=\mathrm{QES}-\mathrm{QSH} .
\end{aligned}
$$

Using these formulas, a negative value means an uptake of nutrients and a positive value a release. Furthermore, the appearance of nutrients in the portal blood (Qavp), or intestinal output, can be measured more simply by the formula: Qavp $=(\mathrm{Cp}-\mathrm{Ca}) \mathrm{Dpdt}$ when the differences (Cp-Ca) are positive (Rérat et al. 1980) whereas BI, based on (Cp-Ca) differences irrespective of whether they are positive (output) or negative (uptake), is the overall result of the absorptive processes, i.e. the intestinal (outputuptake).

The procedures which have allowed the application of this methodology are: a technique of permanent cannulation of the portal vein (Arsac \& Rérat, 1962) and of the carotid artery (Rérat et al. 1980), a procedure for measuring blood flow-rate in the portal vein of the pig (Rérat, 1971; Rérat et al. 1980) and the dog (Elwyn, 1970) by means of an electromagnetic probe. These techniques were improved later by permanent cannulation of a 'suprahepatic' vein and by electromagnetic measurement of blood flow in the hepatic artery (Simoes-Nunes et al. 1985, 1989; Rérat, 1986).

\section{THE KINETICS OF ABSORPTION OF NITROGENOUS NUTRIENTS: VARIATIONS AND THEIR CAUSES}

\section{Kinetics of absorption of amino acids and variations due to the amount and quality of protein supplied}

The enzymic digestion of proteins in the digestive tract not only leads to release of their constitutive amino acids in the gut lumen, but also to that of an even larger amount of small peptides. However, during digestion only traces of small peptides can be found in the blood, apart from some particular cases. Conversely, it was established a long time ago that the blood level of amino acids increases after a meal (Van Slyke \& Meyer, 1912) and that the lymphatic circulation constitutes only a very minor pathway (Dawson \& Porter, 1962). Thus, the digestive hydrolysis of proteins leads mainly to the appearance of amino acids in the blood.

The increase in the blood level of AA observed after a meal in the different 
single-stomached species is less marked, however, in the peripheral than in the portal circulation (Pion et al. 1964) because of the uptake of AA by the liver (Elwyn et al. 1968). The timing, amplitude and duration of the rise in the blood level of the various AA depend on the composition and amount of the dietary proteins ingested and on their transit and digestive hydrolysis characteristics. After a meal, the relationship between the amounts of total and individual amino acids appearing in the portal blood and time are linear, very similar and significant except for a few AA (e.g. glutamic acid; Rérat et al. 1988a). These relationships vary from one protein to another (Rérat, 1988). For example, the hydrolysis products of fish proteins appear more rapidly than those of barley proteins in the portal blood and the differences are all the more marked with increasing levels of ingestion.

Any rise in the level of protein ingestion causes both an increase in the amount of total AA appearing in the portal vein per $\mathrm{h}$, and a decrease in the absorption coefficient in terms of relative value. Hence, the digestive tract responds to an increase in the protein supply by an acceleration of all the digestive processes which, however, is not large enough to cope fully with the additional flux of substrates to be degraded. This regulation of the inputs to the body probably depends on the increase in secretion of some regulatory peptides such as somatostatin (Rérat et al. 1985a). Moreover, the regression lines of absorbed $v$. ingested amounts vary markedly from one AA to another. Thus, for a given protein, each AA has its own characteristics of appearance in the blood which change according to the level of protein ingestion (Rérat et al. 1988a; Rérat, 1988).

The profile of the essential amino acids (EAA) absorbed depends on the mixture of essential amino acids ingested without, however, completely resembling it. When six protein mixtures (fish meal, wheat, barley, maize, rapeseed, casein) were compared (Rérat, 1988), some of the AA were found to have more rapid relative rates of absorption than the average for the mixture; for example, histidine (except in fish meal) and aromatic amino acids (except in rapeseed and casein). Other AA had a rate close to the mean value (branched chain AA and threonine), while others had a rate lower than the mean; for example, arginine and S-containing AA (except casein). In some feeds (fish, wheat, barley) lysine has a lower relative absorption rate than the mean and a somewhat higher rate than the mean in others (maize, rapeseed, casein).

The mixture of absorbed non-essential amino acids (NEAA) undergoes very marked modifications during absorption but the trend is the same for all proteins studied, only the extent of the modification varies. Thus, very large excesses of alanine and glycine and very large deficits of diacids, in particular glutamic acid, are observed.

What are the reasons for these changes in absorption which vary according to the protein source? On the one hand, they are related to the diversity of transport systems for nitrogenous nutrients (small peptides and free AA in variable proportions according to proteins) in the intestinal mucosa where absorption of the nutrients may be inhibited by competition or facilitated. On the other hand, they are influenced by the metabolism of nutrients in the gut mucosa. Evidence for both these causal factors has been provided by an experimental model based on duodenal perfusion of nitrogenous mixtures of the same composition but composed of either small peptides obtained by mild hydrolysis of milk proteins (PEP) or equivalent mixtures of free AA (AAL), in the presence or absence of carbohydrate mixtures (Rérat et al. 1985b, 1988b; Rérat, 1988). This model 
was applied to absorption and metabolism studies over a period of 5-8 $\mathrm{h}$ in pigs subjected to cannulation as described previously.

\section{Influence of the physicochemical structure of the mixtures subjected to absorption: small peptides v. free $A A$}

The absorption rate of each $\mathrm{AA}$ in the free form is different and it varies according to the concentration relative to that of the other AA, because of competition for the various transport systems (Munck, 1981). When AA are present in a more complex form, such as peptides resulting from enzymic hydrolysis, the hierarchy of their absorption rate is different and varies according to the origin and composition of the hydrolysates (Grimble \& Silk, 1989).

However, relatively few in vivo experiments have been carried out on this topic. The criteria for rate of absorption which have been used were either the rate of disappearance of nitrogenous substances from the intestinal lumen of perfused intestinal loops or the rate of appearance of $\alpha-\mathrm{NH}_{2}-\mathrm{N}$ in the peripheral blood. The first approach, which is limited to an isolated loop of gut, is unable to take into account the changes which arise as the nutrients pass through the whole of the intestine. The second approach is obscured by the consequences of liver metabolism. These shortcomings were avoided by measurement of the appearance of AA in the portal vein and their metabolism in the intestinal wall and the liver in pigs receiving successively each of the two aforementioned solutions (PEP v. AAL; Rérat, 1988; Rérat et al. 1988b). Under these conditions, and when the solutions were not admixed with carbohydrates, the amounts of total AA (TAA) absorbed during the $5 \mathrm{~h}$ of observation, were significantly higher after infusion of $106 \mathrm{~g}$ small peptides than after infusion of the same amount of free AA (101v. 58\%). The individual AA followed a pattern of absorption similar to that of TAA. Thus, the appearance of AA in the portal blood was greater, more rapid and more homogeneous after duodenal infusion of a solution of PEP than after infusion of a solution of AAL, irrespective of the amount of the infusate. The coefficient of absorption of most individual AA was higher after infusion of PEP than after infusion of AAL, the differences becoming lower, but more often significant, with the time elapsed after the infusion. However, there were some exceptions. Thus, methionine exhibited a significantly higher absorption coefficient after infusion with AAL and the absorption coefficients of isoleucine, aspartic acid + asparagine and glutamic acid + glutamine were the same for the two types of infusions. Even when absent from the infusates some AA such as asparagine, ornithine and citrulline appeared in the portal blood in rather large quantities after infusion of both types of solutions.

During nutrition with free AA solutions, the competition for absorption sites may be responsible for a change in the composition of the AA mixtures available to the body. However, these consequences of competition might be reduced (Christensen, 1963) by a spatiotemporal regulation since absorption takes place throughout the digestive tract.

After small peptide infusion, the hierarchy of absorption is greatly modified, the highest rate being that of aromatic and basic AA and the lowest rate that of methionine. The more rapid absorption of AA after duodenal infusion of PEP than after infusion of AAL and the modification of the composition of the absorbed mixture may be explained by different competitive processes linked to the existence of specific sites of transport for di- and tripeptides in the intestinal wall (see Grimble \& Silk, 1989). 


\section{Influence of carbohydrates on the absorption of $A A$ according to the physicochemical nature of nitrogenous mixtures supplied}

In the pig, amounts of AA appearing in the portal blood within a given time interval after a meal also depend on the type of non-fibrous and fibrous carbohydrates present in the diet; there is also an interaction of carbohydrate type with the physicochemical form of the dietary nitrogenous compounds. Within $12 \mathrm{~h}$ after the intake of a semi-synthetic meal, the apparent absorption ratio for $\mathrm{NH}_{2}-\mathrm{N}$ decreased from 95 to $76 \%$ when $220 \mathrm{~g}$ lactose $/ \mathrm{kg}$ replaced maize starch in the diet or from 95 to $70 \%$ when the amount of pure cellulose increased from 60 to $160 \mathrm{~g} / \mathrm{kg}$ (Guisi-Perier et al. 1989). The presence of carbohydrates may elicit differences in the kinetics of absorption of AA from different sources. This was shown in the effects of maltose-dextrin on the rates of absorption of AA from AAL and PEP into portal blood (Rérat, 1988; Rérat et al. 1990). When maltose-dextrin was added to AAL solution there was no significant effect on absorption rates of AA except for that of glycine which was significantly depressed for $5 \mathrm{~h}$. In contrast, the addition of maltose-dextrin to PEP solution sharply depressed TAA absorption rates ( $29 \%$ after $1 \mathrm{~h}, 35 \%$ after $5 \mathrm{~h}$ ).

Thus, the overall effect of the maltose-dextrin was to reduce the differences in the absorption rates of AA from AAL and PEP (see p. 338), with the result that after $8 \mathrm{~h}$ the proportion of TAA absorbed from each solution was almost the same (PEP 79\%, AAL $75 \%)$.

\section{Metabolism of hydrolysis products in the enterocyte}

The metabolism of protein hydrolysis products in the gastrointestinal wall is variable, depending on the kinetics of AA absorption and subsequent circulating fluxes. It generally leads to a more or less marked uptake of almost all AA; conversely some of them may be subject to synthesis. The intestinal uptake from the arterial blood is calculated from the negative porto-arterial differences. This uptake was only apparent since a fraction of the absorbed AA coming from the lumen could also be taken up during its transport by the enterocyte. After duodenal infusions of the AA sources (PEP and AAL) in the presence of carbohydrates (Rérat, 1988; Rérat et al. 1992), the apparent uptake of TAA from arterial blood was significantly higher $(P<0 \cdot 05)$ following infusion of AAL than after PEP infusion ( $33 v .24 \%$ of amounts infused respectively). This difference between AAL and PEP may be due to the fact that fluxes of circulating AA were larger $(9 \%, P<0.01)$ after AAL infusion than after PEP infusion. These larger fluxes of free AA make them more available for tissues with a high metabolic rate such as gut tissues. As for EAA, these differences concern mainly lysine but also branched-chain AA (BCAA), which means that intestinal tissues behave like muscle tissues which are avid for these AA (Harper et al. 1984) and this confirms findings reported for the dog (Ferrannini et al. 1988; Abumrad et al. 1989). BCAA could be used for protein synthesis when combined with other AA taken up by the gut wall during their transport from the digestive lumen. In relation to NEAA, there was a large uptake of blood glutamine which agrees with observations of Windmueller \& Spaeth (1975) and Rérat et al. $(1988 a, b)$ and a smaller uptake of glutamic acid, resulting in a low apparent absorption rate of the sum of the two AA. Conversely, there was a marked synthesis of alanine. Alanine production proceeds from glutamine and glutamic acid metabolism (Pion et al. 
1964; Windmueller \& Spaeth, 1980), but probably also from the metabolism of BCAA and pyruvate, as in muscle tissues (Chang \& Goldberg, 1978).

The uptake of AA by the gut wall from the blood might indicate that there was a synthesis of proteins. The extent of protein synthesis depends on the contribution of other sources of AA because poor retention of some individual blood AA could limit synthesis. It is rather difficult to estimate accurately this synthesis, which is generally considered as large, because in addition to the exchanges of AA between the gut cell wall and the blood, there are also exchanges of serum proteins. It seems that in normal subjects, the amounts of serum proteins catabolized or synthesized (Fauconneau \& Michel, 1970) are low. But this emphasizes the involvement in accurate inter-organ balances of not only free AA, but also circulating peptides and proteins.

In conclusion, the kinetics of appearance of AA in the portal blood resulting from the physicochemical structure of the nitrogenous compounds influences the nature of apparent intestinal wall uptake from the arterial blood.

\section{METABOLISM OF AA IN THE LIVER AND PERIPHERAL TISSUES AND VARIATIONS ACCORDING TO THEIR ABSORPTION KINETICS}

\section{Liver metabolism}

After duodenal infusion of solutions of small peptides (PEP) or free amino acids (AAL) in the presence of carbohydrates, the uptake of total AA by the liver paralleled that of the absorption (Rérat, 1988; Rérat et al. 1992). This uptake was very large during the initial period of observation and became small or negative (release) during the final period of the observation; the total balance within $8 \mathrm{~h}$ indicates a relatively large uptake of total amino acids in the liver, varying between $27 \%$ (PEP) and $31 \%$ (AAL) of the infused amounts (or 35 and $42 \%$ respectively of the absorbed amounts). However, the nature of the mixture taken up was different, because it was composed of $100 \%$ EAA after duodenal infusion of PEP and $72 \%$ after that of AAL; the total balance after infusion of small peptides thus resulted in a small decrease in the stock of NEAA in the liver. Whatever the infusion, the AA mixture taken up within $8 \mathrm{~h}$ by the liver was very different from the mixture infused. After PEP infusion, the EAA taken up showed an enrichment in histidine, basic and aromatic AA and an impoverishment in BCAA, S-containing AA and threonine. A similar trend was observed after AAL infusion except that the liver uptake of threonine was identical to the mean uptake and that of methionine was enriched. The NEAA balance was characterized by a very large uptake of alanine, a smaller uptake of glycine and serine and a moderate release of glutamine and aspartic acid and a very large release of glutamic acid (sum of the latter three AA: PEP $19.5 \mathrm{~g} / 8 \mathrm{~h}$, AAL $12.4 \mathrm{~g} / 8 \mathrm{~h}$ ). Uptake of proline after PEP infusion was low but it was higher after AAL infusion. The only significant differences in liver uptake between the two infusions was for tyrosine, $(\mathrm{PEP}>\mathrm{AAL})$ and methionine $(\mathrm{AAL}>\mathrm{PEP})$. With the exception of these differences, the general trends of AA uptake by the liver (high for neoglucogenic AA, aromatic AA, lysine and histidine, low for BCAA) are in agreement with the findings of other authors (Elwyn, 1970; Bloomgarden et al. 1981; Barrett et al. 1986; Ferrannini et al. 1988). By contrast, glutamic acid:glutamine release is reversed in the dog (Elwyn, 1970).

Thus, $8 \mathrm{~h}$ after the infusion, there are still differences in the cumulative uptake or 
release of AA in the hepatic tissues depending on the physicochemical structure of the nitrogenous mixtures.

\section{Metabolism in the peripheral tissues}

Our experimental design enabled us to study separately the liver and the other organs of the splanchnic area (e.g. gut and spleen). Also, it allowed us to obtain indirect information on peripheral tissue metabolism by the difference between total outputs and inputs in the abdominal splanchnic area. The findings should be considered as a whole and the conclusions drawn with caution because the other organs and tissues involved (i.e. muscle, brain, kidneys) are very heterogeneous. It should also be noted that forms of AA other than the free form can be exchanged between tissues, for example proteins secreted by the liver, or glutathione which, in some cases, could constitute more than $50 \%$ of the liver output of $\mathrm{NH}_{2}-\mathrm{N}$ (Elwyn et al. 1968).

In our study (Rérat, 1988; Rerat et al. 1992), the hourly uptake of TAA by the peripheral tissues was large during the first $2 \mathrm{~h}$ whichever of the solutions was infused; it was followed by a small release after some hours. At $8 \mathrm{~h}$ after infusion, the net uptake from PEP was higher than that from AAL (27 and $11 \%$ of the infused amounts respectively) but the difference was not statistically significant.

The uptake of individual AA $8 \mathrm{~h}$ after the infusion showed similar trends for the two infusions. The peripheral uptake of EAA mixture showed an enrichment in BCAA and arginine, and an impoverishment in histidine and aromatic AA (becoming even a release after AAL perfusion). Of the NEAA, there was a high uptake of glutamic acid, and a lower uptake of aspartic acid, and conversely a high release of glutamine, glycine and alanine. However, some marked differences appeared between the two infusions. Thus, there was a release (zero balance for methionine) of S-AA after PEP infusion, and a release of threonine and phenylalanine after AAL infusion; an uptake of proline and serine after PEP infusion $v$. a release after AAL infusion, and a higher release of alanine after AAL infusion than after PEP infusion.

The postprandial peripheral uptake of BCAA is well known (Harper et al. 1984). It probably includes incorporation of these AA into tissue proteins as well as a simple transamination with release, and oxidative metabolism to the corresponding keto acids (Harper et al. 1984; Ferrannini et al. 1988). A proportion of the branched-chain keto acids is probably transferred to the liver for oxidation (Krebs \& Lund, 1977). In relation to NEAA, the output of glutamine has been underestimated because of its renal catabolism for $\mathrm{NH}_{3}$ production and excretion (Welbourne et al. 1972). Muscle disposal of glutamic and aspartic acids after a meal intake is well documented (Elwyn, 1970; Wahren et al. 1976; Gelfand et al. 1986) as well as muscle release of glutamine and alanine (Wahren et al. 1976; Abumrad et al. 1989), the $\mathrm{N}$ of which comes partly from BCAA (Galim et al. 1980).

Thus, the main result of peripheral tissue metabolism of $\mathrm{AA}$ is the formation of $\mathrm{CO}_{2}$ and branched-chain keto acids, which represent a form of transfer of energy to the liver, and output of alanine and glutamine which represent the 'shuttle' for transfer of BCAA-N from the peripheral tissues to the liver for urea formation (Mallette et al. 1969).

Thus, $8 \mathrm{~h}$ after the duodenal infusion, there were great differences in the cumulative uptake or release of free AA by the peripheral tissues depending upon the physico- 
chemical structure of the nitrogenous mixtures used. It should be stressed that the mixture taken up was imbalanced, less so after PEP infusion (no methionine uptake) than after AAL infusion (release of threonine and phenylalanine, absence of NEAA).

\section{METABOLIC CONSEQUENCES}

It seems inevitable that there will be metabolic consequences of the differences in absorption of AA from the gut and uptake by peripheral tissues, which are associated with the different forms in which the mixtures of AA were infused. The fluxes of circulating urea were higher after AAL infusion than after PEP infusion (Rérat et al. 1992), which indicates a higher catabolism of amino acids. This fact is consistent with the biological value of small peptides (NPU 0.28) which was higher $(P<0.01)$ than that of the mixture of free AA (NPU 0.14) in rats in conditions of discontinuous enteral nutrition (Monchi \& Rérat, 1993). The fact that, in spite of release of some free EAA, there could be peripheral protein synthesis means that some peripheral input of AA in a combined form may partially compensate these imbalances. Perhaps peripheral hydrolysis of the labile plasma proteins synthesized in the liver could contribute thus to the inter-organ transport of AA and repletion of peripheral proteins (Elwyn, 1970). The possibility of a high rate of protein synthesis (about $35 \mathrm{~g} / 8 \mathrm{~h}$ ) by the liver during infusions is suggested by the study of urea production and free AA uptake in the liver after these infusions (Rerat et al. 1992) which enabled us to calculate the net non-catabolic metabolism of AA in the liver. This is confirmed when using another type of approach: the possible synthesis of liver proteins may be calculated from the percentage of liver-retained AA which is available to build proteins taking into account the limiting factors (Block \& Mitchell, 1946), i.e. $63 \%$ with S-AA as limiting factors for PEP, and $60 \%$ with valine for AAL. Thus, the rate of liver protein synthesis for $8 \mathrm{~h}$ can be estimated to be $29 \mathrm{~g}$ (PEP) or $25 \mathrm{~g}$ (AAL).

\section{CONCLUSION}

The amounts of AA appearing in the portal blood during digestion are mainly affected by the amount and composition of dietary crude protein, whereas the kinetics of their appearance is also closely related to the physicochemical structure of these proteins. The absorption kinetics seem to be a rather important factor in the temporal distribution of free AA in the tissues, and may be at the origin of transitory imbalances. As a result of these imbalances, the metabolic utilization of AA may be depressed, leading to higher levels of circulating urea fluxes and a lower nutritive value. This possibly explains the differences in the splanchnic fluxes of AA after duodenal infusion of small peptides or free AA. This puts focus on the attention which should be paid to research on the 'time factor' in the relationships between digestive and metabolic utilization of nutrients.

The author thanks Kirsten Rérat for translating the manuscript into English.

\section{REFERENCES}

Abumrad, N. N., Williams, P., Frexes-Steed, M., Geer, R., Flakoll, P., Cercosimo, E., Brown, L. L., Melki, I., Bulus, N., Hourani, H., Hubbard, M. \& Ghishan, F. (1989). Inter-organ metabolism of aminoacids in vivo. Diabetes/Metabolism Reviews 5, 213-226. 
Arsac, M. \& Rérat, A. (1962). Technique de fistulation de la veine porte chez le porc (Technique for fistulation of the portal vein in the pig). Annales de Biologie Animale, Biochimie, Biophysique 2, 335-343.

Barrett, E. J., Gusberg, R., Ferrannini, E., Tepler, J., Felig, P., Jacob, R., Smith, D. \& De Fronzo, R. A. (1986). Amino acid and glucose metabolism in the postabsorptive state and following amino acid ingestion in the dog. Metabolism, Clinical and Experimental 35, 709-717.

Block, R. J. \& Mitchell, H. H. (1946). The correlation of the amino-acid composition of proteins with their nutritive value. Nutrition Abstracts and Reviews 16, 249-278.

Bloomgarden, Z. T., Liljenquist, J., Lacy, W. \& Rabin, D. (1981). Amino acid disposition by liver and gastrointestinal tract after protein and glucose ingestion. American Journal of Physiology 241, E90-E99.

Chang, T. W. \& Goldberg, A. L. (1978). The metabolic fates of aminoacids and the formation of glutamine in the skeletal muscle. Journal of Biological Chemistry 253, 3677-3684.

Christensen, H. N. (1963). Amino acid transport and nutrition. Federation Proceedings 22, 1110-1114.

Dawson, R. \& Porter, J. W. G. (1962). An investigation into protein digestion with ${ }^{14}$ C-labelled protein. 2. The transport of ${ }^{14} \mathrm{C}$-labelled nitrogenous compounds in the rat and cat. British Journal of Nutrition 16, 27-38.

Elwyn, D. H. (1970). The role of the liver in regulation of aminoacid and protein metabolism. In Mammalian Protein Metabolism, vol. 4, pp. 523-557 [H. N. Munro, editor]. New York and London: Academic Press.

Elwyn, D. H., Parikh, H. C. \& Shoemaker, W. C. (1968). Aminoacid movements between gut, liver and periphery in unanesthetized dogs. American Journal of Physiology 215, 1260-1275.

Fauconneau, G. \& Michel, M. C. (1970). The role of the gastrointestinal tract in the regulation of protein metabolism. In Mammalian Protein Metabolism, vol. 4, pp. 481-522 [H. N. Munro, editor]. New York and London: Academic Press.

Ferrannini, E., De Fronzo, R. A., Gusberg, R., Tepler, J., Jacob, R., Aaron, M., Smith, D. \& Barrett, E. J. (1988). Splanchnic aminoacid and glucose metabolism during aminoacid infusion in dogs. Diabetes 37, 227-245.

Galim, E. B., Hruska, K., Bier, D. M., Matthews, D. E. \& Haymond, M. W. (1980). Branched chain amino acid nitrogen transfer to alanine in dogs: Direct isotopic determination with $\left[{ }^{15} \mathrm{~N}\right]$-leucine. Journal of Clinical Investigation 66, 1295-1304.

Geiger, E. (1950). The role of time factor in protein synthesis. Science 111, 594-599.

Gelfand, R. A., Glickman, M. G., Jacob, R., Sherwin, R. S. \& De Fronzo, R. A. (1986). Removal of infused aminoacids by splanchnic and leg tissues in humans. American Journal of Physiology 250, E407-E413.

Giusi-Perier, A., Fiszlewicz, M. \& Rérat, A. (1989). Influence of diet composition on intestinal volatile fatty acids and nutrient absorption in unanesthetized pigs. Journal of Animal Science 67, 386-402.

Grimble, K. G. \& Silk, D. A. (1989). Peptides in human nutrition. Nutrition Research Reviews 2, 87-108.

Harper, A. E., Miller, R. H. \& Block, K. P. (1984). Branched chain aminoacid metabolism. Annual Review of Nutrition 4, 409-454.

Krebs, H. A. \& Lund, P. (1977). Aspects of the regulation of the metabolism of branched-chain aminoacids. Advances in Enzyme Regulation 15, 375-394.

Mallette, L. E., Exton, J. H. \& Park, C. R. (1969). Control of gluconeogenesis from aminoacids in the perfused rat liver. Journal of Biological Chemistry 244, 5713-5723.

Monchi, M. \& Rérat, A. (1993). Net protein utilization of milk protein mild enzymatic hydrolysates and free amino acids mixtures with the same pattern in the rat. Journal of Parenteral and Enteral Nutrition. (In the Press).

Munck, B. G. (1981). Intestinal absorption of amino acids. In Physiology of the Gastrointestinal Tract, vol. 2, pp. 1097-1122 [L. R. Johnson, editor]. New York: Raven Press.

Pion, R., Fauconneau, G. \& Rérat, A. (1964). Variations de la composition en acides aminés du sang porte au cours de la digestion chez le porc. (Variations in the amino acid composition of the portal blood during digestion in the pig). Annales de Biologie Animale. Biochimie, Biophysique 4, 383-401.

Rérat, A. (1971). Mise au point d'une méthode quantitative d'étude de l'absorption chez le porc. (Quantitative method for studying the digestive absorption in the pig). Annales de Biologie Animale. Biochimie, Biophysique 11, 277-279.

Rérat, A. (1986). Utilisation de l'azote des aliments produits par les biotechnologies: cinétique d'absorption, métabolisation et sécrétion d'hormones pancréatiques après perfusion duodénale d'hydrolysats de protéines laitières chez le porc éveillé. (Utilization of nitrogen from foods produced by biotechnologies: kinetics of absorption and metabolism of nutrients and secretion of pancreatic hormones after duodenal infusion of enzymatic hydrolysates of milk proteins in the conscious pig). In Food and Biotechnology, Proceedings of the International Symposium, pp. 215-242 [J. de la Noue, J. Goulet and J. Amiot, editors]. Québec: Université Laval. 
Rèrat, A. (1988). Experimental results on gut physiology and absorption as related to amino-acid nutrition and metabolism. Roche Research Prize for Animal Nutrition, p. 71. Basel: Roche Animal Nutrition and Health.

Rérat, A. \& Bourdon, D. (1975). Supplếmentation retardée à l'aide de lysine industrielle d'une régime déficient en cet acide aminé (Asynchronous supplementation using industrial lysine of a diet deficient in this amino acid). Journées de la Recherche Porcine en France 7, 27-35.

Rérat, A., Chayvialle, A., Kandé, J., Vaissade, P., Vaugelade, P. \& Bourrier, T. (1985a). Metabolic and hormonal effects of test meals with various protein contents in pigs. Canadian Journal of Physiology and Pharmacology 63, 1547-1559.

Rérat, A., Jung, J. \& Kandé, J. (1988a). Absorption kinetics of dietary hydrolysis products in conscious pigs given diets with different amounts of fish protein. 2. Individual amino acids. British Journal of Nutrition 60 , 105-120.

Rérat, A., Simoes-Nunes, C., Lacroix, M., Vaugelade, P. \& Vaissade, P. (1985b). Cinétique comparée d'apparition dans la veine porte de l'azote aaminé provenant de mélanges de petits peptides ou d'acides aminés libres de même composition introduits dans le duodénum chez le porc éveillé (Comparative quantitative intestinal absorption of amino acid mixtures of the same composition offered either in free form or as an enzymatic hydrolysate of milk proteins to conscious pigs). Compte-rendus de l'Académie des Sciences, Paris 300, 293-296.

Rérat, A., Simoes-Nunes, C., Mendy, F. \& Roger, L. (1988b). Amino acid absorption and production of pancreatic hormones in non-anaesthetized pigs after duodenal infusions of milk enzymatic hydrolysate or free amino acids. British Journal of Nutrition 60, 121-136.

Rérat, A., Simoes-Nunes, C., Mendy, F., Vaissade, P. \& Vaugelade, P. (1992). Splanchnic fluxes of aminoacids after duodenal infusion of carbohydrate solutions containing free aminoacids or oligopeptides in the non-anaesthetized pig. British Journal of Nutrition 68, 111-138.

Rérat, A., Simoes-Nunes, C., Vaissade, P. \& Vaugelade, P. (1990). Intestinal absorption of amino acids coming from small peptides or free amino acid solutions infused in the conscious pig duodenum, in the presence of carbohydrates. Reproduction Nutrition Development 30, 136 Abstr.

Rérat, A., Vaugelade, P. \& Villiers, P. A. (1980). A new method for measuring the absorption of nutrients in the pigs: critical examination. In Current Concepts of Digestion and Absorption in Pigs. Technical Bulletin no. 3, pp. 177-216 [A. G. Low and I. G. Partridge, editors]. Reading/Ayr: National Institute for Research in Dairying/Hannah Research Institute.

Simoes-Nunes, C., Rérat, A., Galibois, I., Vaugelade, P. \& Vaissade, P. (1989). Hepatic and gut balances of glucose, amino-nitrogen, ammonia and urea in the pig after ingestion of casein or rapeseed proteins. Nutrition Reports International 40, 901-907.

Simoes-Nunes, C., Rérat, A., Vaugelade, P. \& Vaissade, P. (1985). Simultaneous quantitative study of intestinal absorption and hepatic metabolisation in the conscious pig. Development and interest of the technique. Diabete \& Metabolism 10, 349 Abstr.

Van Slyke, D. D. \& Meyer, G. M. (1912). The amino nitrogen in the blood. Preliminary experiments on protein assimilation. Journal of Biological Chemistry 12, 399-410.

Wahren, J., Felig, P. \& Hagenfeldt, L. (1976). Effect of protein ingestion on splanchnic and leg metabolism in normal man and in patients with diabetes mellitus. Journal of Clinical Investigation 57, 987-999.

Welbourne, T., Weber, M. \& Bank, N. (1972). The effect of glutamine administration on urinary ammonium excretion in normal subjects and patients with renal disease. Journal of Clinical Investigation 51, $1852-1860$.

Windmueller, H. G. \& Spaeth, A. E. (1975). Intestinal metabolism of glutamine and glutamate from the lumen as compared to glutamine from blood. Archives of Biochemistry and Biophysics 171, 662-672.

Windmueller, H. G. \& Spaeth, A. E. (1980). Respiratory fuels and nitrogen metabolism in vivo in small intestine of fed rats. Journal of Biological Chemistry 225, 107-112. 